UDC:

\title{
A case of a ten-year old girl with dominantly inherited Familial Mediterranean fever in Republic of Macedonia
}

\author{
Dragica Bliznakovska Stanchev ${ }^{1}$, Daniela Janjcevic ${ }^{2}$, Dejan Trajkov ${ }^{1}$, \\ Slavica Hristomanova Mitkovska ${ }^{1}$, Meri Kirijas, Olivija Efinska Mladenovska ${ }^{1}$, \\ Olgica Sibinovska ${ }^{1}$, Aleksandar Petlichkovski ${ }^{1 *}$ \\ ${ }^{1}$ Institute of Immunobiology and Human Genetics, Faculty of Medicine, University "Sv Kiril i Metodij", \\ St. "50 Divizija" 6, 1000 Skopje, Macedonia \\ ${ }^{2}$ University Clinic of Clinical Biochemistry-Skopje, Faculty of Medicine, University "Sv Kiril i Metodij", \\ St. "50 Divizija” 6, 1000 Skopje, Macedonia
}

Received: August 2015; Accepted: October 2015

\begin{abstract}
The Familial Mediterranean fever (FMF, MIM249100) is an autoimflammatory genetic disease characterized with recurrent painful attacks in the abdomen, chest or joints, usually accompanied with high body temperature. It is classically inherited in an autosomal recessive manner. It is associated with mutations of the MEFV gene, coding for the protein pyrin. More than 140 mutations of the MEFV gene are defined worldwide. Despite the progress in establishing reliable tests practical for routine use, as much as $20 \%$ of the patients with FMF remain without a detectable mutation in the MEFV gene. This is the main reason why the diagnosis of FMF remains still a clinical one, according to Tel Hashomer criteria.

A 10-year old girl admitted to the Clinic of Pediatrics at the Faculty of Medicine in Skopje for unexplained fever. After numerous laboratory analyses and specialist consultations were done, genetic testing for FMF was requested. The presence of an heterozygous mutation E148Q was confirmed at the Institute for Immunobiology and Human Genetics using a PCR based, reverse hybridization method. Administration of colchicine, the therapy of choice, in a dose of $1.5 \mathrm{mg} /$ day, lead to complete resolution of the symptoms within some days following commencement.

Although the disease is classically inherited in a recessive manner, some atypical cases of autosomal dominant inheritance are described. Our patient may be another example supporting the unusual dominant inheritance, since the heterozygous state for the E148Q mutation was the only positive finding in the genotyping of the 12 most frequent MEFV mutations.
\end{abstract}

Keywords: Familial Mediterranean fever, genetic testing, MEFV E148Q

\section{Introduction}

Familial Mediterranean fever (FMF, MIM249100) is a genetic multi-systemic disease with recurrent painful attacks in the abdomen, chest or joints as a main characteristic. Usually, the attacks are accompanied by high body temperature, and sometimes a skin rush. The disease was recognized as a separate entity in 1945 (Bakkaloglu, 2003). Today, it is known under many names, such as recurrent hereditary polyserositis, benign paroxysmal peritonitis, periodical fever, periodical amyloid syndrome, Armenian syndrome or Reimann's periodical disease (Ben-Chetrit et al., 1998; Booth et al., 2000; Brik et al., 2001; Cazeneuve et al., 1999; Ryan et al., 2010). Most frequently, this

*aleksandar.petlichkovski@medf.ukim.edu.mk 
disease is found in people originating from the Mediterranean region (therefore the name), and classically it is most prevalent in four populations: Sephardi Jews (1/250-1000), Armenians (1/500), Turks (1/1000) and Arabs (1/2600). (Booth et al., 2000; Brik et al., 2001; Cazeneuve et al., 2000; Fujikura et al., 2015). It is significantly less frequent in other populations. A vast number of patients with FMF (80-95\%) are younger than 20 years at the time of diagnosis, while $50-60 \%$ of them are younger than 10 years (Dewalle et al., 1998; El-Shanti 2001). Main complications associated with this disease are destructive oligoarthritis and secondary amyloidosis which could potentially lead to death (Gedalia 2004; Gershoni-Baruch et al., 2003; Gershoni-Baruch et al., 2002; Gershoni-Baruch et al., 2001).

The disease is classically inherited in an autosomal recessive manner. After identification of the gene responsible for the disease MEFV, in 1997, numerous studies have been conducted in order to examine the distribution of different MEFV mutations across populations and the different genotype- phenotype correlation (Brik et al., 2001; Cazeneuve et al., 2000; Gershoni-Baruch et al., 2001; Kishida et al., 2014). The MEFV gene is located on chromosome 13.3 , and codes for a protein called pyrin or marenostrin, expressed only in neutrophils, serosal cells in the peritoneal and pleural spaces and in synovial cells (Haghighat et al., 2006; Kastner 1998). The exact role of the protein is not yet known, but it was shown that it has certain effect on the control of the inflammation, probably through inhibition of C5a and Il-8 (Kubik et al., 2006).

\section{Case presentation}

A 10 year old girl admitted to the Clinic of Pediatrics at the Faculty of Medicine in Skopje sub febrile, with stable vital parameters, pain in the left leg and discrete edema of the leg joints, accompanied with urticarial-like rash of the extremities. During her 13-day stay at the Clinic, repeated temperature rising up to $41{ }^{\circ} \mathrm{C}$ accompanied with fever and rash accentuation. Numerous laboratory tests and consultations with specialists were conducted. In absence of other obvious explanation for the fever, testing for FMF was requested. Presence of a heterozygous mutation E148Q was confirmed by genetic test.; the same detection was noted following father's DNA examination. The detection of the 12 most common MEFV mutations was performed using the commercial FMF StripA kit (ViennaL-

Table 1. Tel Hashomer criteria for diagnosis of Familial Mediterranean Fever (FMF)*

$\begin{array}{lll}\text { Major criteria } & \text { Minor criteria } & \text { Supportive criteria }\end{array}$

\begin{tabular}{|c|c|c|}
\hline $\begin{array}{l}\text { Typical attacks } \\
\text { - Peritonitis (generalized) } \\
\text { - Unilateral pleuritis or peri- } \\
\text { carditis } \\
\text { - Monoarthritis (hip, knee, } \\
\text { ankle) }\end{array}$ & $\begin{array}{l}\text { Incomplete attacks in one or } \\
\text { more of the following sites: } \\
\text { - Abdomen } \\
\text { - Chest } \\
\text { - Joint } \\
\text { - Exertional leg pain } \\
\text { - Positive response to colhicine }\end{array}$ & $\begin{array}{l}\text { - } \text { Family history of FMF } \\
\text { - Adequate ethnic origin } \\
\text { - } \text { Age } \leq 20 \text { at disease onset } \\
\text { - Severe attack } \\
\text { - } \text { Period without symptoms } \\
\text { - Transient inflammatory response supported with }>1 \mathrm{ab-} \\
\text { normal result of white blood cell count, erythrocyte sed- } \\
\text { imentation rate, serum amyloid A. } \\
\text { - } \text { Episodic proteinuria }\end{array}$ \\
\hline
\end{tabular}

* For diagnosing of FMF are required:

$\geq 1$ major criteria, or $\geq 2$ minor criteria, or

1 minor and $\geq 5$ supportive criteria, or

1 minor and $\geq 4$ of the first 5 supportive criteria.

Typical attacks are defined attacks of pain which last shortly (between 12 hours and 3 days), are recurrent ( $\geq 3$ of same type) and accompanied with high body temperature (rectal temperature $\geq 38^{\circ} \mathrm{C}$ ).

Incomplete attacks are defined attacks of pain similar to typical, except:

- Body temperature is not elevated; or

- Attacks last longer or shorter compared to typical;

- During the abdominal painful attacks, there is no sign of peritonitis.

- Abdominal attacks are localized;

- The arthritis is localized in atypical joints. 
ab, VIenna, Austria), based on PCR and reverse hybridization technique. An informed consent was given prior to examination.

\section{Management and outcome}

According to the Tel Hashomer criteria (Table 1) (one major - monoarthritis, one minor - positive response to Colchicine, and five additional - age $\leq 20$, severe attack, spontaneous remission, attack-free period, and occasional inflammatory episodes with abnormal (high) leukocyte count and/or ESR), a diagnosis of FMF was assigned. The therapy of choice, colchicine, was prescribed orally in a dose of $1.5 \mathrm{mg}$ /day, which lead to complete resolution of the symptoms following two days of treatment.

\section{Discussion}

In reviewing the spectrum and the penetrance of different mutations of the MEFV gene, it seems that three mutation hotspots are identified, namely codons 148, 680, and 694. A total of more than 140 mutations of the MEFV gene are by now reported worldwide (Matzner et al., 1984). However, it is evident only five of them are globally responsible for the majority (some 70\%) of the FMF cases, namely mutations V726A, M694V, M694I, M680I and E148Q (Matzner et al., 1984; Pras et al., 1998; Mijatovic et al., 2003, Mohammadnejad, 2013). Despite the obvious progress in the last decade in establishing molecular tests convenient for routine use, as much as $20 \%$ of the patients with FMF remain without a detectable mutation in the MEFV gene and the diagnosis still relies on clinical criteria. Another important characteristic of the disease is the diversity of symptoms and their varying severity in different patients. Notably, this high heterogeneity is not always in parallel with the type of the mutation, although some mutations are believed to confer a more severe presentation $(726,694)$ whereas some other a less severe one (148) i.e. the clinical presentation of certain genotypes in homozygous, heterozygous or combined heterozygous patients (Jéruet al 2013; Shohat et al., 1999; Shinawi et al., 2000; Tchernitchko et al., 2003 Touitu, 2001). This points out to potential modifying factors, such as gender, MEFV and other modifying mutations. Obviously, other, not yet identified population factors that influence the clinical manifestation of the disease cannot be excluded.

Although the disease is classically inherited in a recessive manner, some atypical cases of autosomal dominant inheritance are described. This finding was confirmed in two separate families, one with Ashkenazi, and the other with Georgian origin. By following the FMF in 4 successive generations of family members, it was confirmed that in both cases the underlying mutation responsible for the unusual inheritance was E148Q (OMIM 607108.0005), present in heterozygous state. Again however, the role of other not as-yet identified pyrin gene mutations cannot be excluded.

Our patient may be another case supporting the unusual dominant inheritance, since the heterozygous state for the E148Q mutation was the only positive finding in the genotyping of the 12 most frequent MEFV mutations. It would be interesting to perform DNA sequencing of the entire MEFV gene in this patient (we are currently arranging it), in order to exclude possibly present genetic deviations other than the twelve mutations analyzed.

\section{References}

Bakkaloglu, A., 2003. Familial Mediterranean fever. Pediatr. Nephrol. 18(9), 583-589.

Ben-Chetrit, E., Levy, M., 1998. Familial Mediterranean fever. The Lancet 1(351), 659-664.

Booth, D.R., Gilmore, J.D., Lachmann, H.J., Booth, S.E., Soytruk, M., Akar, S., Pepys, M.B., Tunca, M., Hawkins, P.N., 2000. The genetic basis of autosomal dominant familial Mediterranean fever. Q. J. Med. 93, 217- 221.

Brik, R., Shinawi, M., Kasinetz, L., Gershoni-Baruch, R., 2001.The musculoskeletal manifestations of familial Mediterranean fever in children genetically diagnosed with the disease. Arthritis Rheum. 44, 1416- 1419.

Cazeneuve, C., Sarkisian, T., Pecheux, C., Dervichian, M., Nedelec, B., Reiert, P., Ayvazyan, A., Kouyoumdjian, J.C., Ajrepetyan, H., 1999. MEFV-gene analysis in Armenians patients with FMF: diagnostic value, unfavorable renal prognosis of the M694V homozygous genotype, genetic and therapeutic implications. Am. J. Hum. Genet. 65, 88- 97.

Cazeneuve, C., Ajrapetyan, H., Papin, S., Roudot Thoraval, F., Genevieve, D., Mndjoyan, E., Papazian, M., Sarkisi, M., Babloyan, A., Boissier, B., 2000. Identification of MEFV-independent modifying genetic factors for familial Mediterranean fever. Am. J. Hum. Genet. 67, 1136-1143.

Dewalle, M., Domingo, C., Rozembaum, M., BenChertit, E., Cattan, D., Barnot, A., Dross, Ch., Dupont, M., Notarnicola, C., Levy, M., Rosner, I., Demaille, J., Touitou, I.,1998. Phenotypegenotype correlation in Jewish patients suffering from familial Mediterranean fever (FMF). Eur. J. Hum. Genet. 6, 95-97.

El-Shanti, H.E., 2001. Familial Mediterranean Fever. Saudi. Med. J. 22(2), 104-109.

Fujikura, K., 2015.Global epidemiology of Familial Mediterranean fever mutations using population exome sequences. Mol. Genet. Genomic Med. 3(4), 272-282.

Gedalia, A., 2004. Familial Mediterranean fever, in: Nelson Text book of pediatrics, $17^{\text {th }}$ ed. W. B. Saunders Company, pp. 821-822.

Gershoni-Baruch, R., Shinawi, M., Leah, K., Badarnah, K., Brik, R., 2001. Familial Mediterranean fever: prevalence, penetrance and genetic drift. Eur. J. Hum. Genet. 9, 634637.

Gershoni-Baruch, R., Brik, R., Shinawi, M., Livneh, A., 2002. The differential contribution of MEFV mutant alleles to the clinical profile of familial Mediterranean fever. Eur. J. Hum. Genet. 10, 145-149.

Gershoni-Baruch, R., Brik, R., Zacks, N., Shinawi, M., Lidar,M., Livneh, A. 2003. The contribution of genotypes at the 
MEFV and SAA1 loci to amyloidosis and disease severity in patients with familial Mediterranean fever. Arthritis Rheum. 48, 1149- 1155 .

Haghighat, M., Derakhshan, A., Karamifar, H., 2006. Familial Mediterranean fever. Shiraz E Medical Journal 7(2), 1-18.

Jéru, I., Hentgen, V., Cochet, E., Duquesnoy, P., Le Borgne, G.,Grimprel, E., Stojanovic, KS., Karabina, S., Grateau, G., Amselem, S., 2013. The risk of familial Mediterranean fever in MEFV heterozygotes: a statistical approach. PLoS ONE 8(7), e68431. doi:10.1371/journal.pone.0068431.

Kastner, D.L., 1998. Familial Mediterranean fever: The genetics of inflammation. Hospital Practice 15, 131-158.

Kishida, D., Nakamura, A.,Yazaki, M., Tsuchiya-Suzuki, A., Matsuda, M., Ikeda, S., 2014. Genotype-phenotype correlation in Japanese patients with familial Mediterranean fever: differences in genotype and clinical features between Japanese and Mediterranean populations. Arthritis Res. Ther. 16(5), 439. doi: 10.1186/s13075-014-0439-7.

Kubik, N.J ${ }^{\text {3rd }}$., Katz, J.D., 2000. Familial Mediterranean Fever. Am. J. Orthop. 29(7), 553-555.

Livneh, A., Langevitz, P., 2000. Diagnostic and treatment concerns in familial Mediterranean fever. Baillieres Best Pract. Res. Clin. Rheumatol. 14(3), 477-498.

Matzner, Y., Partridge, R.E., Levy, M., Babuior, B.M., 1984. Diminished activity of a chemotactic inhibitor in synovial fluids from patients with familial Mediterranean fever. Blood 63(3), 629.

Mijatovic, V., Hompes, P.G., Wouters, M.G., 2003. Familial Mediterranean fever and its implications for fertility and pregnancy. Eur. J. Obstet. Gynecol. Reprod Biol. 108(2), 171-176.

Mohammadnejad, L., Farajnia, S., 2013. Mediterranean fever gene analysis in the azeriturk population with familial mediterranean Fever: evidence for new mutations associated with disease. Cell J. 15(2), 152-159.

Pras, M., 1998. Familial Mediterranean fever: from the clinical syndrome to the cloning of the pyrin gene. Scand. J. Rheumatol. 27(2), 92-97.

Ryan, J.G., Masters, S.L., Booty, M.G., Habal, N., Alexander, J.D., Barham, B.K., Remmers, E.F., Barron, K.S., Kastner, D.L., Aksentijevich, I., 2010. Clinical features and functional significance of the P369S/R408Q variant in pyrin, the familial Mediterranean fever protein. Ann. Rheum. Dis. 69(7), 1383-1388.

Shinawi, M., Brik, R., Berant, M., Kasinetz, L., GershoniBaruch, R., 2000. Familial Mediterranean fever: high gene frequency and heterogeneous disease among an Israeli-Arab population. J. Rheumatol. 27, 1492-1495.

Shohat, M., Magal, N., Shohat, T., Shen, X., Dagan, T., Mimouni, A., Danon, Y., Lotan, R., Ogur, G., Sirin, A., Schlezinger, M., Halpern, G.J., Schwabe, A., Kastner, D., Rotter, J.I., FischelGhodsian, N., 1999. Phenotype -genotype correlation in familial Mediterranean fever: evidence for an association between Met694Val and amyloidosis. Eur. J. Hum. Genet. 7, 287-292.

Tchernitchko, D., Legendre, M., Cazeneuve, C., Delahaye, A., Niel, F., Amselem, S., 2003.The E148Q MEFV allele is not implicated in the development of familial Mediterranean fever. Hum. Mutat. 22, 339-340.

Touitu, I., 2001. The spectrum of Familial Mediterranean Fever (FMF) mutations. Eur. J. Hum. Genet. 9, 473-483.

Yepiskoposyan, L., Harutyunyan, A., 2007. Population genetics of familial Mediterranean fever: a review. Eur. J. Hum. Genet. 15, 911-916. 


\title{
Резиме
}

\section{Приказ на случај со доминантно наследена фамилијарна медитеранска треска од Република Македонија}

\author{
Драгица Близнаковска Станчев ${ }^{1}$, Даниела Јаничевиќ ${ }^{2}$, Дејан Трајков ${ }^{1}$, \\ Славица Христоманова Митковска ${ }^{1}$, Мери Киријас ${ }^{1}$, Оливија Ефинска Младеновска ${ }^{1}$, \\ Олгица Сибиновска ${ }^{1}$, Александар Петличковски ${ }^{1 *}$

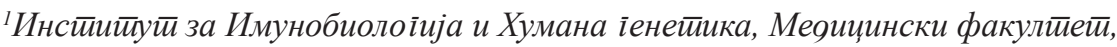 \\ Улица ,,50 Дивизија“ бр. 6, 1000 Скойје, Р. Макеоонија \\ ${ }^{2}$ Универзииетиска Клиника за Клиничка биохемија, Меоицински факулиеиеи. \\ Улица „50 Дивизија“ бр. 6, 1000 Скойје, Р. Макеоонија
}

Клучни зборови: Фамилијарна медитеранска треска, генетско тестирање, MEFVE148Q.

Фамилијарна медитеранска треска (ФМФ, МІМ249100) е автоинфламаторнагенетска болест која се карактеризира со повторливи болни напади во пределот на стомакот, градите или зглобовите, обично придружена со висока телесна температура. Таа класично се наследува автосомно рецесивно и еповрзана со мутации на MEFV генот, кој го кодира протеинот пирин. До сега, повеќе од 140 мутации во MEFVгенотсе дефинирани во светот. И покрај напредокот,во технологијата и воведувањетона тестови практични за рутинска употреба, околу $20 \%$ од пациентите со ФМФ остануваат без откриена мутација во MEFVгенот. Ова е главната причина зошто дијагнозата на ФМФ останува уште клиничка, според TelНаshomerкритериумите. Десет годишно девојче е примено на Клиниката за педијатрија на Медицинскиот факултет во Скопје заради необјаснива треска. Бројни лабораториски анализи и специјалистички консултации беа направени и поради недостаток на објаснение за треската,побарано е генетско тестирање за ФМФ. Присуството на хетерозиготна E148Q мутација беше потврдено на Институтот за Имунобиологија и хумана генетика со користење на методот реверзнахибридизација. Терапијата со колхицин, лек на избор, во доза од 1,5 mg/ден, доведе до потполно повлекување на симптомите по само неколку дена.

Иако болеста класично се наследува по рецесивен начин, опишани се некои атипични случаи на автозомно доминантно наследување. Нашиот пациент може да биде уште еден случај за поддршка на овој необичен начин на доминантно наследување, бидејќ хетерозиготната мутација E148Q е единствениот позитивен наод во генотипизација на 12 најчести MEFV мутации. 